\title{
Upper Gastrointestinal Endoscopy and Children Digestive Pathology in Abidjan
}

\section{Aboubacar Demba Bangoura1, Henriette Ya Anzouan Kissi-Kacou'1, Stanislas Doffou1, Constant Assi², Mamert Fulgence Yao Bathaix ${ }^{1}$, Alain Koffi Attia ${ }^{1}$, Aya Thérèse Ndri-Yoman' ${ }^{1}$}

${ }^{1}$ Hepatogastroenterology Unit, Yopougon Teaching Hospital, Yopougon, Ivory Coast

${ }^{2}$ Hepatogastroenterology Unit, Cocody Teaching Hospital, Cocody, Ivory Coast

Email: bangousmed@gmail.com

How to cite this paper: Bangoura, A.D., Kissi-Kacou, H.Y.A., Doffou, S., Assi, C., Bathaix, M.F.Y., Attia, A.K. and Ndri-Yoman, A.T. (2016) Upper Gastrointestinal Endoscopy and Children Digestive Pathology in Abidjan. Open Journal of Gastroenterology, 6, 265-274.

http://dx.doi.org/10.4236/ojgas.2016.610031

Received: September 23, 2016

Accepted: October 18, 2016

Published: October 21, 2016

Copyright $\odot 2016$ by authors and Scientific Research Publishing Inc. This work is licensed under the Creative Commons Attribution International License (CC BY 4.0).

http://creativecommons.org/licenses/by/4.0/

\begin{abstract}
The aim of our study is to determine the demographic data, indications, performance, and security of gastroscopy in children in Ivory Coast. Patients and Methods: This is a retrospective analytical study based on reports of upper digestive endoscopy performed in children (from 1 day to 15 years included) in 2 university hospitals in Abidjan from March 2009 to March 2016. Results: 276 upper gastrointestinal endoscopies (UGIE) were performed in children during the study period. UGIE was performed with a diagnostic purpose in most cases (99\%). The indications of UGIE were abdominal pains (38.95\%), ingestion of caustic substances (29.82\%), upper gastrointestinal bleeding (10.87\%) and vomiting (10.17\%). UGIE was normal in $39.49 \%$ of cases for all ages. The main anomalies observed in upper gastrointestinal (GI) endoscopy for all ages were gastropathies (29\%); caustic lesions (13.02\%) and bile reflux (10.45\%). Ulcers were rarely found (2.54\%). Histological examination of biopsies revealed chronic $H$. pylori gastritis in $67 \%$ of gastric samples examined. All endoscopic examinations were performed without incident. Conclusion: Gastroscopy is a harmless examination with a great diagnostic and therapeutic utility in digestive pathology of children in Ivory Coast.
\end{abstract}

\section{Keywords}

Upper Gastrointestinal Endoscopy, Children, Abidjan, Ivory Coast

\section{Introduction}

Upper gastrointestinal endoscopy (UGIE) or gastroscopy is a test that allows visual exploration of the inner walls (mucosa) of the esophagus, the stomach and the duodenum to detect anomalies, and sample tissues (biopsies) for histological study. 
Since its introduction in children in the 1970s, gastrointestinal endoscopy has rapidly developed to become one of the most commonly used explorations in pediatric gastroenterology [1] [2]. The development of flexible endoscopes with small caliber and the experience of the operators have made possible gastroscopy at any age including the newborn.

Upper gastrointestinal diseases are common in children worldwide and digestive endoscopy despite its invasive nature plays an important role in their explorations [3].

Several African [4]-[12] and European [13] [14] [15] studies were interested in gastrointestinal endoscopy in children. We notice a large variability of indications, of the practice or not of sedation and/or biopsies, of lesions observed during these studies.

In this manuscript, the authors have studied the demographic data, indications, performance, and security of gastroscopy in children in Ivory Coast.

\section{Patients and Methods}

This is a retrospective analytical study based on reports of upper gastrointestinal endoscopy performed in 2 university hospitals in Abidjan over a period of 7 years from March 2009 to March 2016. Both University Hospitals have digestive endoscopy units for adults receiving both adults and children. These endoscopy units have video-endoscopy Fujinon brand column with gastroscopes for adults with medium caliber $9 \mathrm{~mm}$ and pediatric with small caliber $5 \mathrm{~mm}$ and $7.8 \mathrm{~mm}$. These endoscopy centers receive both inpatients and outpatients. The exams are usually performed by skillful gastroenterologists assisted by a nurse specialist in digestive endoscopy. All of the pediatric patients (aged from1day to 15 years included) in which upper GI endoscopy was performed during the study period were included in the study. The patients aged over 15 years in which upper GI endoscopy was performed during the study period were excluded from the study.

For each child's record included in the study, we provided the information as follows:

-Demographic data: age, gender.

-Indications of UGIE.

-Results of upper gastrointestinal endoscopy.

-Practice of sedation or not (substance used for sedation)

-Performance or not of biopsies (site of biopsies and their indication).

-Presence or absence of a reported incident during the exam.

The children included in the study were distributed in 4 groups according to age: Newborn (from 0 to 28 days), Infant (from 29 days to 23 months), Small children (from 2 to 6 years), Child (from 6 to 12 years) and adolescents (from 12 to 15 years).

We have grouped under the term of abdominal pains, any kind of abdominal pains that motivated the performance of gastroscopy (epigastric pain, ulcer syndrome, dyspeptic syndrome, retrosternal pains, abdominal pains poorly systematized).

All data were collected using a survey form. 


\section{Results}

The authors showed that 276 upper gastrointestinal endoscopies (UGIE) were performed in children during the study period.

These 276 UGIE accounted for 3.30\% of all upper gastrointestinal endoscopies (8314) performed in the 02 university hospitals during the study period. The age of our children ranged from 21 days to 15 years with a mean age of 7.97 years and a median of 09 years. More over it was noted a female predominance with a sex ratio male/female of 0 . 92.

Teenagers were the most represented age group with a frequency of $36.73 \%$.

UGIE was performed with a diagnostic purpose in most cases $99 \%$ and with therapeutic purpose in only 03 cases (foreign body extraction). The indications of UGIE were dominated by abdominal pains (38.95\%), ingestion of caustic substances (29.82\%), upper gastrointestinal hemorrhage (10.87\%) and vomiting (10.17\%) (Table 1 and Table 2). However the indications vary depending on the age of the children. Abdominal pains represent the leading indication in adolescents (over $68 \%$ of cases) and children (in over $55 \%$ of cases).

Table 1. Sociodemographic and clinical characteristics of children.

\begin{tabular}{|c|c|c|}
\hline Characteristic & Number $(n)$ & Percentage (\%) \\
\hline \multicolumn{3}{|l|}{ Age group } \\
\hline New born & 1 & 0.003 \\
\hline Infant & 55 & 18.50 \\
\hline Small children & 58 & 21.09 \\
\hline Child & 65 & 23.64 \\
\hline Adolescent & 101 & 36.73 \\
\hline \multicolumn{3}{|l|}{ Sex } \\
\hline Male & 132 & 47.79 \\
\hline Female & 144 & 52.21 \\
\hline \multicolumn{3}{|l|}{ Indications of UGIE } \\
\hline Diagnostic procedure: & 273 & 98.05 \\
\hline Abdominal pain & 111 & 38.95 \\
\hline Ingestion of caustic products & 85 & 29.82 \\
\hline Upper gastrointestinal (UGI) bleeding & 31 & 10.87 \\
\hline Vomiting & 29 & 10.17 \\
\hline Gastrooesophageal reflux & 10 & 3.50 \\
\hline Liver cirrhosis (portal hypertension research) & 9 & 3.15 \\
\hline Dysphagia & 4 & 1.40 \\
\hline Antropylorique stenosis & 1 & 0.35 \\
\hline Failure to thrive & 1 & 0.35 \\
\hline Halitosis & 1 & 0.35 \\
\hline Therapeutic procedure: & 3 & 1.05 \\
\hline Ingestion of foreign body & 3 & 1.05 \\
\hline
\end{tabular}


Table 2. Indications of UGIE and their variations depending on the age of children.

\begin{tabular}{cccccc}
\hline & Adolescent N (\%) & Children N (\%) & $\begin{array}{c}\text { Small } \\
\text { children N (\%) }\end{array}$ & $\begin{array}{c}\text { New born } \\
\text { and infant N (\%) }\end{array}$ & Total N (\%) \\
\hline $\begin{array}{c}\text { Abdominal pain } \\
\text { Ingestion of caustic }\end{array}$ & $70(67.96)$ & $36(55.38)$ & $4(6.52)$ & $1(1.78)$ & $111(38.95)$ \\
UGI bleeding & $4(3.88)$ & $7(10.76)$ & $40(65.20)$ & $34(60.71)$ & $85(29.82)$ \\
Vomiting & $7(6.79)$ & $13(20.00)$ & $6(9.78)$ & $3(5.35)$ & $29(10.17)$ \\
$\begin{array}{c}\text { Gastrooesophageal } \\
\text { reflux }\end{array}$ & $6(5.82)$ & $0(0.00)$ & $2(3.26)$ & $2(3.57)$ & $10(3.50)$ \\
$\begin{array}{c}\text { Liver cirrhosis } \\
\text { Dysphagia }\end{array}$ & $8(7.76)$ & $1(1.53)$ & $0(0.00)$ & $0(0.00)$ & $9(3.15)$ \\
$\begin{array}{c}\text { Ingestion } \\
\text { of foreign body } \\
\text { antropylorique } \\
\text { stenosis }\end{array}$ & $3(2.91)$ & $0(0.00)$ & $1(1.63)$ & $0(0.00)$ & $4(1.40)$ \\
$\begin{array}{c}\text { Failure to thrive } \\
\text { Halitosis }\end{array}$ & $0(0.00)$ & $1(1.53)$ & $1(1.63)$ & $1(1.78)$ & $3(1.05)$ \\
$\quad$ Total & $0(0.00)$ & $0(0.00)$ & $1(1.63)$ & $0(0.00)$ & $1(0.35)$ \\
\hline
\end{tabular}

For small children and infants UGIE was performed for accidental ingestion of caustic substances in over $65 \%$ of cases, in small children and 60\% in infants (Table 2).

Sedation was done during UGIE with either midazolam or by intravenous diazepam. The dose administered depended on the age of children. It was carried out in 123 children among the $276(44.57 \%)$ and it improved the tolerance of the examination (Figure 1).

UGIE was normal in $39.49 \%$ of cases for all ages and lesions were found in nearly $60 \%$ of cases. The most common site of lesions was gastric (45.36\%) followed by esophagus $(20.28 \%)$. Cardial $(3.26 \%)$ and duodenum $(7.2 \%)$ were rarer. The main anomalies observed in upper GI endoscopy for all ages were gastropathy (29\%); caustic lesions (13.02\%) and bile reflux in (10.45\%).

Ulcers were rarely found with a frequency of $2.54 \%$ for bulbar ulcer and $0.72 \%$ for gastric ulcer. These ulcers were found in children and adolescents and were revealed by abdominal pains in most cases.

Apart from these lesions, it was observed a case of malignant squamous cell carcinoma of the esophagus $0.36 \%$ in an adolescent revealed by dysphagia, 14 cases of esophageal varices $5.07 \%$ and 5 cases of peptic esophagitis $1.81 \%$ (Table 3 ).

Biopsies were performed in only 49 children out of the 276 (17.75\%). The most common site of biopsies was gastric (97.96\%) against only 02 esophageal biopsies. Histological examination of biopsies revealed chronic $H$. pylori gastritis in $67 \%$ of examined samples and squamous cell carcinoma of the esophagus. Tolerance of gastroscopy was generally good in most cases (over $63 \%$ of cases). It was improved with age and sedation.

All endoscopic examinations were performed without incident. 


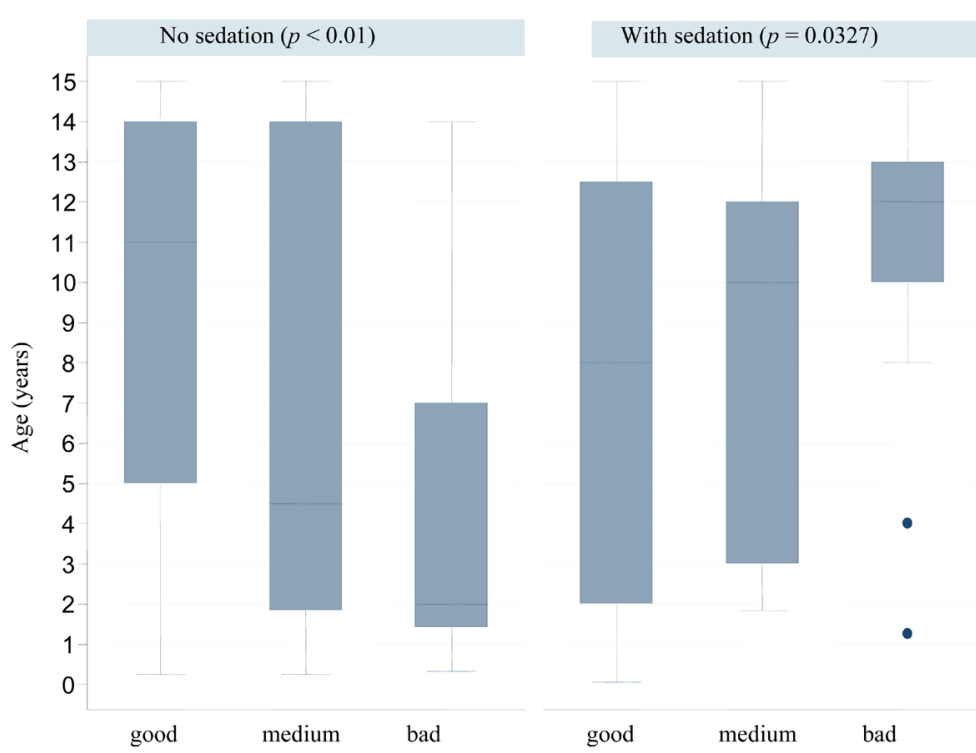

Figure 1. Distribution tolerance depending on the age and sedation.

Table 3. Upper gastrointestinal endoscopy finding in children.

\begin{tabular}{|c|c|c|}
\hline & Number (N) & Percentage (\%) \\
\hline Normal findings & 109 & 39.49 \\
\hline Esophagus & 56 & 20.28 \\
\hline Oesophageal varices & 14 & 1.81 \\
\hline Caustic oesophagitis & 13 & 4.71 \\
\hline Caustic stenosis & 13 & 4.71 \\
\hline Oesophageal mycoses & 6 & 2.17 \\
\hline Reflux oesophagitis & 5 & 1.45 \\
\hline Oesophageal foreign body & 4 & 5.07 \\
\hline Oesophageal tumor & 1 & 0.36 \\
\hline Cardia & 9 & 3.26 \\
\hline Hiatal hernia & 4 & 1.45 \\
\hline Incompetent cardial & 3 & 0.72 \\
\hline Mallory Weiss & 2 & 1.08 \\
\hline Stomach & 126 & 45.36 \\
\hline Gastropathy & 82 & 29.52 \\
\hline Bile reflux & 29 & 10.45 \\
\hline Caustic gastritis & 10 & 3.6 \\
\hline Antropylorique stenosis & 3 & 1.08 \\
\hline Gastric ulcers & 2 & 0.72 \\
\hline DUODENUM & 20 & 7.2 \\
\hline Duodenitis & 12 & 2.52 \\
\hline Duodenal ulcers & 7 & 0.36 \\
\hline Duodenal stenosis & 1 & 4.32 \\
\hline
\end{tabular}




\section{Discussion}

Despite its key role in the exploration of the digestive pathology of children the child's UGIE accounted for only 3.3\% of all upper gastrointestinal endoscopies performed during the study period. This low rate is common to African studies with frequencies from $1.2 \%$ to $6.5 \%$ [4] [5] [6] [8].

The frequent failure of the technical facilities and the lack of pediatric gastroenterology department in these countries explain the fact that UGIE there is not commonly performed in children. Unlike European series teenagers are the age groups most represented in our study and in several African studies [4] [5] [6] due to the lack of pediatrician gastroenterologist. The presence of these specialists would better refine the indications for upper gastrointestinal endoscopies in small children and infants in our country.

Although indications for upper gastrointestinal endoscopy are well codified in children according to the consensus of the SFED (French Digestive endoscopy Society) and GFHGNP(French Hepatology, Gastroenterology and Pediatric Nutrition Group) [16], there is a variability of indications based on studies.

In the literature of most developing countries, recurrent abdominal pains were reported as the most frequent indications for upper gastrointestinal endoscopy in children. Several studies demonstrate it with frequencies ranging from $22 \%$ to $90 \%$ [5] [6] [7] [8] [9] [17]. These abdominal pains are the primary reason for the performance of gastroscopy in our study with a frequency of $38.45 \%$ for all ages. They are especially common in children after 6 years (child and adolescent) in whom they alone represent over $70 \%$ of indications. Our data are consistent with data from the literature of these developing countries.

However in similar studies of Jantchou in France [13], Mouzan in Saudi Arabia [17] and Toufouki in Morocco [12], the malabsorption syndrome was the major indication of performance of upper gastrointestinal endoscopy with frequencies of $27 \%-40 \%$. This syndrome has not been found as an indication in our study. The malabsorption syndrome helps suspect celiac disease whose jejunal biopsy remains the gold standard diagnosis [12].

Celiac disease is a rare disease in our area, however the importance of upper gastrointestinal endoscopy in children affected by chronic diarrhea should be raised among pediatricians in our context.

The ingestion of caustic substance remains a frequent accident in children, even if the prognosis is usually benign [18] [19]. Severe digestive lesions can be observed developing into sequelar strictures responsible for significant mortality. It was found in 85 cases in our study that is $(29.80 \%)$ of indications of UGIE in children. It predominates in the infants and small children (over $60 \%$ of indications) as pointed out by other authors [18] [19] [20] [21].

Upper gastrointestinal bleeding is an extremely common medical and surgical emergency in children and is a sign of alarm. It represents an extreme indication for the performance of upper gastrointestinal endoscopy between the $6^{\text {th }}$ and $24^{\text {th }}$ hour in a 
clinically stable child with no sign of active bleeding. Aoulou [11] and Boudabbous [10] reported it as the most common reason for performing upper gastrointestinal endoscopy in their series in $37 \%$ and $43 \%$ of cases. However it has represented only $11 \%$ of indications in our children, $10.44 \%$ for Lawson [5], and 9.73\% for Toufiki [12]. These results show that upper GI bleeding remains common in children and the observed differences are probably due to sampling fluctuations. Upper gastrointestinal endoscopy is the key to lesion diagnosis of upper gastrointestinal bleeding with a high profitability of over $70 \%$ [10].

Despite the low rate of gastroscopy in children the diagnostic profitability was good (nearly 60\%). In this study, the most commonly observed lesions in upper gastrointestinal endoscopy were gastropathies as in many developing countries studies where abdominal pains were the main indication for upper gastrointestinal endoscopy [5] [8] [9] [22] [23].

The high frequency of gastropathies in these studies is correlated to the high prevalence of $H$. pylori infection in developing countries $(60 \%-80 \%)$ [24]. In Ivory Coast it various from $53 \%$ to $91 \%$ [24] [25] [26].

In the industrialized countries, particularly in France where the prevalence of this infection is relatively low 5\% - 10\% [27], the study of Anicicleroy in Lille [14] found $8.64 \%$ of gastropathies and that of Poissy hospital 13\% [12]. These results show that H.pylori is the first etiological factor of chronic gastritis as Diomandé [26] Attia [28] and Bougouma reported [29].

Ulcers are rare in our study, 2.52\% (7 cases) for duodenal ulcers and $0.72 \%$ ( 2 cases) for gastric ulcer. These ulcers were more common after 6 years and were revealed by abdominal pains in most cases. The rarity of ulcers was observed by other authors [10] [11].

Esophageal varices are relatively rare in children, $0.49 \%$ in the series of Lawson [5], $2 \%$ in that of Christina [30] and 5.07\% in ours. They are encountered at all ages and most often diagnosed during the upper gastrointestinal bleeding. Unlike the study of Lawson [5] where no biopsy was performed, we notice the performance of biopsies in 49 children (17.75\%). Almost all (45/49) of these biopsies were sampled from the stomach (03 antral, 02 fundic, 01 angular) to search for chronic Helicobacter pylori (H.pylori) gastritis. These biopsies were performed mainly in children and adolescents seen in endoscopy for abdominal pains.

The histological examination allowed to objectify a case of squamous cell carcinoma of the esophagus in a 15-year-old child and 30 cases of $H$. pylori infection (67\%). These results confirm the rarity of malignant tumor diseases in children on the one hand and on the other hand the high prevalence of $H$. pylori infection in Ivory Coast. Given these findings gastric biopsy (looking for H.pylori) must be systematic in children seen in endoscopy for abdominal pains.

The lack of technical facilities and financial resources explain the low rate of interventional endoscopy (1.05\%) performed in children in our context (03 foreign body extractions). 
UGIE was performed without incident for all our children. The complication rate of this examination in children is only $2.3 \%$ [31]. The majority of the complications is related to anesthesia. Sedation was performed in $44 \%$ and mainly restricted to teenagers. It improved the tolerance of the examination.

\section{Conclusion}

The authors conclude that gastroscopy is a harmless examination with a great diagnostic and therapeutic utility in digestive pathology of children in Ivory Coast. However, it is not of commonly practice in children at an early age. The etablishment of a pediatric gastroenterology departement is necessary for a best practice of digestive endoscopy in children in our country.

\section{References}

[1] Mougeot, J.F. and Polononovski, C. (1981) La fibroscopie digestive haute de l'enfant. Archives Françaises de Pédiatrie, 38, 807-814.

[2] Ament, M.E., Berquist, W.E., Vargas, J. and Perisic, V. (1988) Fiberoptic Upper Intestinal Endoscopy in Infant and Children. Pediatric Clinics of North America, 35, 141-155. http://dx.doi.org/10.1016/S0031-3955(16)36404-5

[3] Lambert, R. (1999) Digestive Endoscopy: Relevance of Negative Findings. Italian Journal of Gastroenterology and Hepatology, 31, 761-772.

[4] Balaka, B., Redah, D., Konutse, A.Y., et al. (2003) Apport de la fibroscopie digestive haute au diagnostic des lésions œesogastroduodénales pédiatriques: Etude de 144 cas. Journal de la Recherche Scientifique de I'Universite de Lome, 7, 193-198.

[5] Lawson-Ananissoh, L.M., Bouglouga, O., Bagny, A., Kaaga, L., El Hadj Yakoubou, R. and Redah, D. (2015) Panorama des affections oesogastroduodénales chez les enfants de moins de 20ans au Togo. Médecine d' afrique Noire, 62.

[6] Alatise, O.I., Anyabolu, H.C., Sowande, O. and Akinola, D. (2015) Paediatric Endoscopy by Adult Gastroenterologists in Ile-Ife, Nigeria: A Viable Option to Increase the Access to Paediatric Endoscopy in Low Resource Countries. African Journal of Paediatric Surgery, 12, 261-265. http://dx.doi.org/10.4103/0189-6725.172568

[7] Mudawi, H.M., El Tahir, M.A., Suleiman, S.H., Eltaybe, N.H., Gamer, N.M., Abdallha, F.A. and Ibrahim, S.Z. (2009) Pediatric Gastrointestinal Endoscopy: Experience in a Sudanese University Hospital. Eastern Mediterranean Health Journal, 15, 1027-1031.

[8] Okello, T.R. (2006) Upper Gastrointestinal Endoscopic Findings in Adolescents at Lacor Hospital, Uganda. African Health Sciences, 6, 39-42.

[9] Kawami, E., Machado, R.S., Fonseka, J.R., et al. (2004) Clinical and Histological Features of Duodenal Ulcer in Children and Adolescents. Journal of Pediatrics, 80, 321-325. http://dx.doi.org/10.2223/JPED.1207

[10] Boudabbous, M., Gargouri, L., Chtourou, L., Mnif, L., Amouri, A. and Tahri, N. (2014) Indications et apport de la fibroscopie digestive haute chez l'enfant. A propos de 592 cas. Journal Africain d Hépato-Gastroentérologie, 8, 125-129.

[11] Aloulou, H., Maaloul, I., Yaich, S., et al. (2011) La fibroscopie digestive chez l'enfant: indications et resultats experience d'un service de pédiatrie generale. Journal de Pédiatrie et de Puériculture, 24, 111-117. http://dx.doi.org/10.1016/j.jpp.2011.03.006

[12] Toufiki, S. and Sbihi, M. (2008) Apport de la fibroscopie digestive haute chez l'enfant. 
These de medecine.Faculté de médecine de pharmacie de Marrakech Thèse No. 24.

[13] Jantchou, P., Schirrer, J. and Bocquet, A. (2007) Appropriateness of Upper Gastrointestinal Endoscopy in Children: A Rétrospective Study. Journal of Pediatric Gastroenterology and Nutrition, 44, 440-445. http://dx.doi.org/10.1097/MPG.0b013e31802c6847

[14] Anicic-Leroy, C. and Evrard-Lemaire, I. Place de la fibroscopie digestive haute chez l'enfant Thèse de Lille: 1993-314. (Résumé)

[15] Lifschitz, C.H. (1994) Indications de l'endoscopie du tractus digestif supérieur chez le nourrisson, l'enfant et l'adolescent. Acta Endoscopica, 24, 125-128.

[16] Lachaux, A., Michaux, L. and Violla, S. (2009) Consensus en endoscopie digestive pédiatrique. Acta Endoscopica, 4, 322-326. http://dx.doi.org/10.1007/s10190-009-0092-1

[17] El-Mouzan, M.I., Al-Mofleh, I.A., Abdallah, A.M. and Al-Rashed, R.S. (2004) Indications and Yield of Upper Gastrointestinal Endoscopy in Children. Saudi Medical Journal, 25, 1223-1225.

[18] Dabadie, A., Rossey, M., Oumal, M., Betremieux, P., Fremont, B. and Babut, J.M. (1989) Ingestion Accidentelle de caustiques chez l'enfant. A propos de 100 cas observations. Archives de Pédiatrie, 46, 217-222.

[19] Cardona, J., Boussement, T., Berthier, M. and Oriot, D. (1990) Ingestion Accidentelle d'eau de javel chez l'enfant : Enquête auprès de 11centres antipoisons. Proposition et cat Pédiatrie, 48, 705-709.

[20] Bautista Casanovas, A. and Estevezmartinez, E. (1997) A Retrospective Analysis of Ingestion of Caustic Substances by Children. Ten-Year Statistics in Galicia. European Journal of Pediatrics, 156, 410-414. http://dx.doi.org/10.1007/s004310050627

[21] Matoussi, N., Azzouz, E. and Khaldi, F. (2005) Les ingestions de caustiques chez l'enfant étude épidémiologique: A propos de 589 cas. Revue Maghrébine de Pédiatrie, 15, 151-158.

[22] Joshi, J.R., Sharma, S.K. and Baral, M.R. (2005) Upper GI Endoscopy in Children in an Adult Suite. Kathmandu University Medical Journal(KUM), 3, 111-114.

[23] Tam, P.K. and Saing, H. (1989) Pediatric Upper Gastrointestinal Endoscopy: A 13-Year Experience. Journal of Pediatric Surgery, 24, 443-447. http://dx.doi.org/10.1016/S0022-3468(89)80398-7

[24] Megraud, F. (1998) Epidemiology and Mechanism of Antibiotic Resistance in Helicobacter pylori. Gastroenterology, 115, 1278-1282.

[25] Attia, K.A., N'dri Yoman, T., Mahassadi, A., Bathaix, Y.F., et al. (2004) La prévalence de l'infection à H. pylori en milieu scolaire: Resultats de deux ecoles pilotes. Gastroenterologie Clinique et Biologique, 28, 134.

[26] Diomande, M.I., Fléjou, J.F., Potet, F., Dago-Akribi, A., et al. (1991) Gastrites chroniques et infection à Helicobacter pylori en Côte-d'Ivoire: Etude d'une serie de 277 patients symptomatiques. Gastroenterologie Clinique et Biologique, 15, 711-716.

[27] Bicheler, V., Bruley de Varannes, S., Zerbib, F., Megraud, F. and Galmiche, J.P. (2000) Séroprévalence de l'infection à Helicobacter pylori, dans une population adulte saine de l'ouest de la France. Gastroenterologie Clinique et Biologique, 24, A37. (Abstract)

[28] Attia, K.A., N’dri Yoman, T., Diomandé, M.I., Mahassadi, A., et al. (2001) Clinical, Endoscopic and Histologic Aspects of Chronic Helicobacter pylori Gastritis in Côte d'Ivoire: Study of 102 Patients. Bulletin de la Société de Pathologie Exotique, 94, 5-7.

[29] Ilboudo, D., Sangare, L., Sanou, J., Bougouma, A. and Diomande, I. (1997) Aspects épidemiologiques et cliniques de l'infection à Helicobacter pylori en zone tropicale à propos de 150 cas. Médecine de Afrique Noire, 44.

[30] Ferreira, C.T., Berti, M.R., Pires, A.L.G., Wieczorek, C. and Alves, J. (1998) Endoscopia di- 
gestiva alta em pediatria: Indicações e resultados. Jornal de Pediatria, 74, 39-44.

[31] Thakkar, K., El Serag, H.B., Mattek, N. and Gilger, M.A. (2007) Complications of Pediatric EGD: A 4-Year Experience in PEDS-CORI. Gastrointestinal Endoscopy, 65, 213-221.

http://dx.doi.org/10.1016/j.gie.2006.03.015

Submit or recommend next manuscript to SCIRP and we will provide best service for you:

Accepting pre-submission inquiries through Email, Facebook, LinkedIn, Twitter, etc.

A wide selection of journals (inclusive of 9 subjects, more than 200 journals)

Providing 24-hour high-quality service

User-friendly online submission system

Fair and swift peer-review system

Efficient typesetting and proofreading procedure

Display of the result of downloads and visits, as well as the number of cited articles

Maximum dissemination of your research work

Submit your manuscript at: http://papersubmission.scirp.org/

Or contact ojgas@scirp.org 